\title{
Nanoparticles in inhibiting Pantoea ananatis and to control maize white spot
}

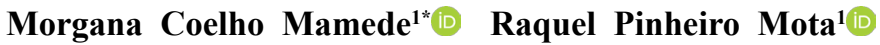 \\ Anielle Christine Almeida Silva ${ }^{2}$ Nilvanira Donizete Tebaldi ${ }^{1}$ (iD
}

${ }^{1}$ Instituto de Ciências Agrárias, Universidade Federal de Uberlândia (UFU), 38.400-902, Uberlândia, MG, Brasil. E-mail: morganacmamede@gmail.com. "Corresponding author.

${ }^{2}$ Laboratório de Novos Materiais Nanoestruturados e Funcionais, Instituto de Física, Universidade Federal de Alagoas (UFAL), Maceió, AL, Brasil.

ABSTRACT: Maize white spot (MWS) caused by Pantoea ananatis is one main maize leaf diseases, and nanoparticles (NPs) are an innovative approach for bacterial disease control. This research evaluated the toxicity of pure NPs and doped NPs with different elements in inhibiting bacterial growth and to control MWS. Pure NPs and ZnO NPs doped with silver (Ag), gold (Au), copper (Cu), iron (Fe), manganese (Mn), and nickel (Ni) at different concentrations were used to determine the toxicity for P. ananatis in vitro, evaluating the bacterial growth inhibition zone. To assess the control of MWS, in the preventive application, maize plants were sprayed with $\mathrm{NPs}$ of $\mathrm{ZnO}: 0.1 \mathrm{Cu}, \mathrm{ZnO}: 0.05 \mathrm{Fe}, \mathrm{ZnO}: 0.2 \mathrm{Mn}$ and

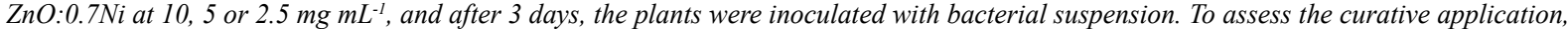
plants were inoculated with the bacteria, and 3 days later sprayed with the NPs. The disease severity was assessed and the area under the disease-progress curve (AUDPC) was calculated. The doped ZnO NPs with different elements, and at different concentrations inhibited bacterial growth in vitro. NPs of $\mathrm{ZnO}: 0.1 \mathrm{Cu}$ and $\mathrm{ZnO}: 0.2 \mathrm{Mn}$ at 5 or $2.5 \mathrm{mg} \mathrm{mL} \mathrm{L}^{-1}$, in both applications reduced the severity of $\mathrm{MWS}$, showing potential for use in the disease management.

Key words: bactericidal, nanocrystals, severity, Zea mays.

Nanopartículas na inibição de Pantoea ananatis e no controle da mancha branca do milho

RESUMO: A mancha branca do milho (MBM) causada por Pantoea ananatis é uma das principais doenças foliares da cultura, e as nanopartículas (NPS) surgem como inovação no controle de doenças bacterianas. O objetivo do presente trabalho foi avaliar a toxidez de NPs puras e dopadas com diferentes elementos, na inibição do crescimento bacteriano e no controle da MBM. NPs puras e NPs de ZnO dopadas com: prata (Ag), ouro ( $\mathrm{Au}$ ), cobre (Cu), ferro ( $\mathrm{Fe}$ ), manganês ( $\mathrm{Mn}$ ), e níquel (Ni) em diferentes concentrações foram usadas para determinar a toxidez à P. ananatis, avaliando-se o halo de inibição do crescimento bacteriano. Para avaliar o controle da MBM, na aplicação preventiva, plantas de milho foram pulverizadas com NPs de $\mathrm{ZnO}: 0.1 \mathrm{Cu}, \mathrm{ZnO}: 0.05 \mathrm{Fe}$, ZnO:0.2Mn e ZnO:0.7Ni a 10, 5 e $2.5 \mathrm{mg} \mathrm{mL}^{-1}$, e três dias depois foram inoculadas com a suspensão bacteriana. Na aplicação curativa, as plantas foram inoculadas com a suspensão bacteriana e três dias após pulverizadas com as NPS. A severidade da doença foi avaliada e calculada a área abaixo da curva de progresso da doença (AACPD). NPs de $\mathrm{ZnO}$ dopadas com os diferentes elementos e concentrações inibiram o crescimento bacteriano in vitro. As NPs de ZnO:0.1Cu e ZnO:0.2Mn

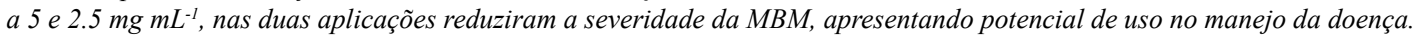

Palavras-chave: bactericida, nanocristais, severidade, Zea mays.

Maize white spot (MWS) caused by the bacterium Pantoea ananatis (PACCOLAMEIRELLES et al., 2001) can cause losses of over $60 \%$ in production, mainly in conditions of moderate temperature $\left(14{ }^{\circ} \mathrm{C}\right)$ and high relative humidity $(>60 \%)$ (CASELA et al 2006). The use of resistant hybrids and the application of fungicides is recommended as measures of disease control (PEDRO et al., 2012).

Bacterial diseases are difficult to control once established in the field (COSTA et al., 2012), and innovative strategies should be evaluated for their control, such as the use of nanoparticles (NPs). NPs have reduced size (less than $100 \mathrm{~nm}$ ), high reactivity (KAH \& HOFMANN, 2014), and biocidal efficacy, interacting with the microbial membrane due to the high surface/volume ratio (ALLAKER, 2010).

Several NPs have been synthesized in the search for an efficient, biocompatible, and specific material, such as oxides of inorganic metals (SILVA et al., 2018). Zinc oxide (ZnO) NPs have high catalytic activity, chemical/physical stability, and biocompatibility (HE et al., 2019), generating interest in formulations for agricultural purposes. Its semiconductor nature induces the formation of

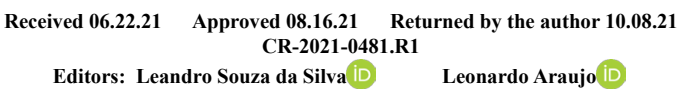


reactive oxygen species (ROS), leading to oxidative stress and cell death (SABIR et al., 2014) .

To increase the bactericidal effect, $\mathrm{ZnO}$ NPs may be doped with different elements, which consists of the integration of new elements in the $\mathrm{NP}$, enhancing and changing its physical, electronic, and chemical structure (SILVA et al., 2018). In the management of plant diseases the doped ZnO NPs have already been described for the control of Fusarium spp, Xanthomonas axonopodis pv. citri, Xanthomonas oryzae pv. oryzae, Clavibacter michiganensi, Xanthomonas perforans, Pseudomonas syringae and Xanthomonas gardneri (ELMER \& WHITE, 2016; BALLOTTIN et al., 2017; RIVAS-CÁCERES et al., 2018; LIAO et al., 2019; ELSHARKAWY et al., 2020; FRAGA et al., 2021).

However, studies of NPs doped with different chemical elements and concentrations are required for suggesting alternatives for MWS control. Therefore, this study evaluated the toxicity of pure NPs, and ZnO NPs doped with silver, gold, copper, iron, manganese, and nickel to inhibit Pantoea ananatis growth in vitro, and the efficacy of $\mathrm{ZnO}$ NPs doped with copper, iron, manganese, and nickel in preventive and curative applications for the control of MWS

The Pantoea ananatis strain (UFU A18) preserved and maintained in the research collection of the Laboratório de Bacteriologia Vegetal (LABAC), Instituto de Ciências Agrárias, Universidade Federal de Uberlândia (UFU), Minas Gerais was grown using the 523 growth media (KADO \& HESKETT, 1970) for 48 hours at $28{ }^{\circ} \mathrm{C}$. The bacterial suspension was prepared in sterile filtered water and adjusted to $\mathrm{OD}_{550}$

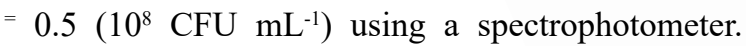
The Pantoea ananatis was confirmed by PCR using the species-specific primer pair ANAf/ANAr, that amplify a fragment of 389-bp (FIGUEIREDO \& PACCOLA-MEIRELES 2012; SAUER et al. 2015)

To evaluate its bacterial activity, $\mathrm{ZnO}$ NPs doped with silver $(\mathrm{Ag})$, gold $(\mathrm{Au})$, copper $(\mathrm{Cu})$, iron $(\mathrm{Fe})$, manganese $(\mathrm{Mn})$, and nickel $(\mathrm{Ni})$ at different concentrations, as well as the pure NPs of $\mathrm{AgO}, \mathrm{Au}$, $\mathrm{CuO}, \mathrm{FeO}, \mathrm{MnO}, \mathrm{NiO}$, and $\mathrm{ZnO}$ were tested (Table 1). The NPs approximate size was $20 \mathrm{~nm}$, and they were synthesized at the Laboratory for New Insulating and Semiconductor Materials, at UFU's Physics Institute, according to the methodology described by SILVA et al. (2018). Each NP was prepared using distilled sterile water at concentrations 100 and $10 \mathrm{mg} \mathrm{mL}^{-1}$.

The NPs were used to evaluate the inhibition zone of $P$. ananatis in vitro. A basic layer of $2 \%$ agar-water medium and semi-solid nutrient medium $(0.8 \%)$, supplemented with $10 \%$ of the

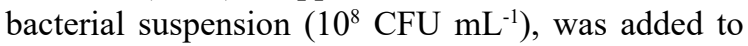
Petri dishes $(8 \mathrm{~cm})$. Five sterile filter paper disks $(6 \mathrm{~mm})$ were placed onto the medium and soaked with $10 \mu \mathrm{L}$ of each NP solution, $500 \mu \mathrm{g} \mathrm{mL}{ }^{-1}$ of streptomycin (positive control), and filtered sterile water (negative control). After incubation at $28{ }^{\circ} \mathrm{C}$ for 48 hours the diameter of the inhibition zone was measured in centimeters.

The experiment was performed in a factorial scheme with completely randomized design, with 6 doped NPs at different concentrations, 7 pure NPs, in 2 dilutions (100 and $\left.10 \mathrm{mg} \mathrm{mL}^{-1}\right)$, plus 2 additional ( $\mathrm{ZnO}$ and pure NP), and streptomycin and sterile filtered water as control treatments, each

Table 1 - Concentrations of doped and pure nanoparticles (NP).

\begin{tabular}{|c|c|c|c|c|c|c|c|}
\hline \multirow{2}{*}{$\begin{array}{l}\text { Doped NP } \\
\mathrm{ZnO}: \mathrm{Ag}\end{array}$} & \multicolumn{6}{|c|}{ - } & \multirow{2}{*}{$\begin{array}{c}\text { Pure NP } \\
\mathrm{Ag}_{2} \mathrm{O}\end{array}$} \\
\hline & 0.7 & 1 & 3 & 7 & 9 & 11 & \\
\hline $\mathrm{ZnO}: \mathrm{Au}$ & 0.1 & 0.5 & 1 & 5 & 10 & & $\mathrm{Au}$ \\
\hline $\mathrm{ZnO}: \mathrm{Cu}$ & 0.1 & 0.4 & 1 & 4 & 12 & & $\mathrm{CuO}$ \\
\hline $\mathrm{ZnO}: \mathrm{Fe}$ & 0.05 & 0.5 & 3 & 7 & 11 & & $\mathrm{FeO}$ \\
\hline $\mathrm{ZnO}: \mathrm{Mn}$ & 0.2 & 0.4 & 0.8 & 4 & 8 & 12 & $\mathrm{MnO}$ \\
\hline \multirow[t]{2}{*}{$\mathrm{ZnO}: \mathrm{Ni}$} & 0.7 & 1 & 3 & 11 & & & $\mathrm{NiO}$ \\
\hline & & & & & & & $\mathrm{ZnO}$ \\
\hline
\end{tabular}

ZnO: (Zinc oxide) doped with: Ag (Silver), $\mathrm{Au}$ (Gold), $\mathrm{Cu}$ (Copper), Fe (Iron), Mn (Manganese), $\mathrm{Ni}$ (Nickel), $\mathrm{Ag}_{2} \mathrm{O}$ (Silver oxide), CuO (Copper oxide), $\mathrm{FeO}$ (Iron oxide), $\mathrm{MnO}$ (Manganese oxide), $\mathrm{NiO}$ (Nickel oxide). 
with 3 replicates. The data obtained were subjected to analysis of variance and the means were compared using the Tukey test, and Dunnett test at 5\% probability using R v 4.0.2 (R CORE TEAM, 2020). $\mathrm{NPs}$ of $\mathrm{ZnO}: 0.1 \mathrm{Cu}, \mathrm{ZnO}: 0.05 \mathrm{Fe}$, $\mathrm{ZnO}: 0.2 \mathrm{Mn}, \mathrm{ZnO}: 0.7 \mathrm{Ni}$ were selected for subsequent assessments due to the amount of the product available in the laboratory, and the cost of synthesis.

To evaluate the control of MWS, two assays were carried out at different times, in a greenhouse. Hybrid maize plants $\mathrm{P} 1630 \mathrm{H}$ were grown in 500 $\mathrm{mL}$ pots containing soil, sand, and vermiculite (3: 1: 1). After 15 days of sowing (at 3 to 4 leaf stage), for assessing preventive application, leaves were sprayed until runoff with NPs solutions $\mathrm{ZnO}: 0.1 \mathrm{Cu}$, $\mathrm{ZnO}: 0.05 \mathrm{Fe}, \mathrm{ZnO}: 0.2 \mathrm{Mn}, \mathrm{ZnO}: 0.7 \mathrm{Ni} \mathrm{NPs}$ at 10 or 5 $\mathrm{mg} \mathrm{mL}^{-1}$ (first assay), and 5 or $2.5 \mathrm{mg} \mathrm{mL}^{-1}$ (second assay), and water. After 3 days, the plants leaves were sprayed with bacterial suspension $\left(10^{8} \mathrm{CFU} \mathrm{mL}^{-1}\right)$. Similarly, the plants used for assessing the curative application were sprayed with bacterial suspension and, after 3 days, were sprayed with the treatment solutions described above. The plants were kept in a humid chamber 24 hours before and after inoculation.

The severity of MWS was assessed at 3, 6, 9, and 12 days after inoculation, using a scale ranging from 0 to 4 , where: $0=$ leaf without symptoms, $1=1$ to $25 \%$ of the leaf is injured, $2=$ 26 to $50 \%$ of the leaf is injured, $3=51$ to $75 \%$ of the leaf is injured, $4=$ above $75 \%$ of the leaf is injured (SILVA \& TEBALDI, 2018).

The area under the disease-progress curve (AUDPC) was calculated using the formula: AUDPC $=\Sigma\left(\left(Y_{i}+Y_{i+1}\right) / 2\right)\left(t_{i+1}-t_{i}\right)$, in which $Y$ is disease intensity; $t$ is time (interval between evaluations, in days); and $\mathrm{i}$ is the number of assessments made over time (CAMPBELL \& MADDEN, 1990).

The experimental design comprised an $8 \times 2+1$ factorial scheme with 8 treatments (4 NPs $x$ 2 concentrations), 2 applications (preventive and curative) +1 additional (water application), and 4 replicates. The data obtained were subjected to an analysis of variance, and the means were compared using the Scott-Knott test, and Dunnett test at 5\% probability using R v 4.0.2 (R CORE TEAM, 2020).

The different concentrations of $\mathrm{ZnO}$ NPs doped with $\mathrm{Ag}, \mathrm{Au}, \mathrm{Cu}, \mathrm{Fe}, \mathrm{Mn}$ or $\mathrm{Ni}$ at $100 \mathrm{mg} \mathrm{mL}^{-1}$ and $10 \mathrm{mg} \mathrm{mL}^{-1}$ inhibited bacterial growth, the halos ranging from 0.6 to $1.1 \mathrm{~cm}$ (Table 2). As well as, pure $\mathrm{NPs}$ of $\mathrm{CuO}, \mathrm{NiO}, \mathrm{Au}$, or $\mathrm{Ag}_{2} \mathrm{O}$ at $100 \mathrm{mg} \mathrm{mL}^{-1}$ with inhibition zone ranging from 0.23 to $0.63 \mathrm{~cm}$. The largest inhibition zone was observed using the $\mathrm{ZnO}: \mathrm{Ag}$ NPs, even though at different concentrations of the doping elements. In the controls there was bacterial growth for water, and inhibition halo for streptomycin.

The antibacterial action of NPs can occur due to the destabilization, degradation or dissolution of cell membranes and bacterial biofilm; thereby, reducing protection, and enabling interaction with internal compounds, causing deregulation or promotion of the release of toxic ions; which can lead to the physical blocking of the cell transport channels or the oxidation of membrane lipids by ROS (DURÁN et al., 2016; BALLOTTIN et al., 2017; WANG et al., 2017). Previous studies have shown that the application of different concentrations of $\mathrm{Ag}$ NP can inhibit the growth or kill microorganisms as Xanthomonas perforans (OCSOY et al., 2013), Pseudomonas sp. (ARAÚJO et al., 2015), Xanthomonas axonopodis pv. citri (BALLOTTIN et al., 2017), and Clavibacter michiganensis subsp. michiganensis (RIVAS-CÁCERES et al., 2018).

The structural damage caused by Ag NPs occurs due to the dissipation of the protons from the bacterial membrane, which leads to cell death (DURÁN et al., 2016). The antibacterial property of Ag NPs have been described to Xanthomonas perforans, with morphological changes like cell deformation, and destruction of the membrane(OCSOY et al., 2013).

The antimicrobial action of $\mathrm{ZnO}: \mathrm{Au}$ NPs was observed in several concentrations of the doping element, except for $\mathrm{ZnO}: 10 \mathrm{Au}$ NPs (Table 2), this could be explained due to high concentration of the element, more aggregation of the product occurs and; consequently, a decrease of the exposed reactive surface area of the NPs with the microorganism, reducing the bactericide action. The biocidal mechanism of $\mathrm{ZnO}: \mathrm{Au}$ NPs (CUI et al., 2012) is due to alterations in the membrane permeability, which improve cell wall binding and penetration properties, providing a higher concentration of photoactive molecules (ALLAKER, 2010).

$\mathrm{ZnO}: \mathrm{Cu}$ NPs had shown better effect biocidal in lower dilution $\left(10 \mathrm{mg} \mathrm{mL}^{-1}\right)$, which can be explained by the high solubility of $\mathrm{Cu}$ ions in different concentrations, forming ROS that degrade microbial membranes (AHAMED et al., 2014). Cubased products are usually applied for the control of bacteriosis because of their good performance, nevertheless when they are nanostructured, such as $\mathrm{ZnO}: \mathrm{Cu}$, the biocidal efficacy increases as described to Escherichia coli (KEZHEN et al., 2020). The antibacterial activity of $\mathrm{ZnO}: 0.15 \mathrm{Ni}$ NPs was related to Streptococcus mutans and Pseudomonas aeruginosa in vitro with high effect to Gram negative bacteria (VIJAYAPRASATH et al., 2016). 
Table 2 - Pantoea ananatis growth inhibition halo $(\mathrm{cm})$ by nanoparticles $(\mathrm{NP})$ at 100 and $10 \mathrm{mg} \mathrm{mL}^{-1}$.

\begin{tabular}{|c|c|c|c|c|c|c|c|}
\hline \multirow{2}{*}{$\begin{array}{l}\text { Doped NP } \\
\mathrm{ZnO}: \mathrm{Ag}\end{array}$} & \multicolumn{6}{|c|}{-----------------------------------Concentrations of doping elements-------------------------------- } & \multirow{2}{*}{$\begin{array}{c}\text { Pure NP } \\
\mathrm{Ag}_{2} \mathrm{O}\end{array}$} \\
\hline & 0.7 & 1 & 3 & 7 & 9 & 11 & \\
\hline $100 \mathrm{mg} \mathrm{mL}^{-1}$ & $0.8 \mathrm{Ac}^{*}{ }^{*}$ & $0.95 \mathrm{Ab}+{ }^{*}$ & $1.0 \mathrm{Ab}+{ }^{*}$ & $1.0 \mathrm{Ab}+^{*}$ & $1.0 \mathrm{Ab}+{ }^{*}$ & $1.1 \mathrm{Aa}^{*}$ & 0.63 \\
\hline $10 \mathrm{mg} \mathrm{mL}^{-1}$ & $0.0 \mathrm{Bc}+$ & $0.75 \mathrm{Bb}+^{*}$ & $0.95 \mathrm{Aa}^{*}$ & $1.0 \mathrm{Aa}+^{*}$ & $0.95 \mathrm{Aa}^{*}$ & $1.0 \mathrm{Ba}+^{*}$ & \\
\hline $\mathrm{ZnO}: \mathrm{Au}$ & 0.1 & 0.5 & 1 & 5 & 10 & & $\mathrm{Au}$ \\
\hline $100 \mathrm{mg} \mathrm{mL}^{-1}$ & $0.6 \mathrm{Ab}+^{*}$ & $0.7 \mathrm{Aa}^{*}{ }^{*}$ & $0.7 \mathrm{Ba}^{*}$ & $0.7 \mathrm{Aa}^{*}{ }^{*}$ & $0.0 \mathrm{Ac}+$ & & 0.41 \\
\hline $10 \mathrm{mg} \mathrm{mL}^{-1}$ & $0.6 \mathrm{Ac}+{ }^{*}$ & $0.7 \mathrm{Ab}+^{*}$ & $0.8 \mathrm{Aa}+^{*}$ & $0.7 \mathrm{Ab}+^{*}$ & $0.0 \mathrm{Ad}+$ & & \\
\hline $\mathrm{ZnO}: \mathrm{Cu}$ & 0.1 & 0.4 & 1 & 4 & 12 & & $\mathrm{CuO}$ \\
\hline $100 \mathrm{mg} \mathrm{mL}^{-1}$ & $0.0 \mathrm{Bb}+$ & $0.9 \mathrm{Aa}^{*}{ }^{*}$ & $0.0 \mathrm{Bb}+$ & $0.0 \mathrm{Bb}+$ & $0.0 \mathrm{Ab}+$ & & 0.48 \\
\hline $10 \mathrm{mg} \mathrm{mL}^{-1}$ & $0.9 \mathrm{Aa}^{*}{ }^{*}$ & $0.95 \mathrm{Aa}+^{*}$ & $0.9 \mathrm{Aa}^{*}{ }^{*}$ & $0.8 \mathrm{Ab}+^{*}$ & $0.0 \mathrm{Ac}+$ & & \\
\hline $\mathrm{ZnO}: \mathrm{Fe}$ & 0.05 & 0.5 & 3 & 7 & 11 & & $\mathrm{FeO}$ \\
\hline $100 \mathrm{mg} \mathrm{mL}^{-1}$ & $0.0 \mathrm{Ab}$ & $0.85 \mathrm{Aa}^{*}{ }^{*}$ & $0.0 \mathrm{Ab}$ & $0.0 \mathrm{Ab}$ & $0.0 \mathrm{Ab}$ & & 0.0 \\
\hline $10 \mathrm{mg} \mathrm{mL}^{-1}$ & $0.0 \mathrm{Ab}$ & $0.7 \mathrm{Ba}+^{*}$ & $0.0 \mathrm{Ab}$ & $0.0 \mathrm{Ab}$ & $0.0 \mathrm{Ab}$ & & \\
\hline $\mathrm{ZnO}: \mathrm{Mn}$ & 0.2 & 0.4 & 0.8 & 4 & 8 & 12 & $\mathrm{MnO}$ \\
\hline $100 \mathrm{mg} \mathrm{mL}^{-1}$ & $0.0 \mathrm{Bc}$ & $0.9 \mathrm{Aa}+^{*}$ & $0.7 \mathrm{Bb}+{ }^{*}$ & $0.7 \mathrm{Ab}+^{*}$ & $0.0 \mathrm{Ac}$ & $0.0 \mathrm{Ac}$ & 0.0 \\
\hline $10 \mathrm{mg} \mathrm{mL}^{-1}$ & $0.7 \mathrm{Ab}+^{*}$ & $0.7 \mathrm{Bb}+^{*}$ & $0.8 \mathrm{Aa}+^{*}$ & $0.65 \mathrm{Bc}+{ }^{*}$ & $0.0 \mathrm{Ad}$ & $0.0 \mathrm{Ad}$ & \\
\hline $\mathrm{ZnO}: \mathrm{Ni}$ & 0.7 & 1 & 3 & 11 & & & $\mathrm{NiO}$ \\
\hline $100 \mathrm{mg} \mathrm{mL}^{-1}$ & $0.8 \mathrm{Aa}+{ }^{*}$ & $0.0 \mathrm{Ab}+$ & $0.0 \mathrm{Ab}+$ & $0.0 \mathrm{Ab}+$ & & & 0.23 \\
\hline $10 \mathrm{mg} \mathrm{mL}^{-1}$ & $0.8 \mathrm{Aa}^{*}{ }^{*}$ & $0.0 \mathrm{Ab}+$ & $0.0 \mathrm{Ab}+$ & $0.0 \mathrm{Ab}+$ & & & \\
\hline \multicolumn{8}{|l|}{$\mathrm{ZnO}$} \\
\hline $100 \mathrm{mg} \mathrm{mL}^{-1}$ & 0.0 & & & & & & \\
\hline $10 \mathrm{mg} \mathrm{mL}^{-1}$ & 0.0 & & & & & & \\
\hline \multicolumn{8}{|l|}{$\mathrm{H}_{2} \mathrm{O}$} \\
\hline \multicolumn{8}{|l|}{0.0} \\
\hline \multicolumn{8}{|l|}{ Streptomycin } \\
\hline $500 \mu \mathrm{g} \mathrm{mL}^{-1}$ & 1.2 & & & & & & \\
\hline
\end{tabular}

Means followed by uppercase letters in the column and lowercase letters in the row differ by the Tukey test at $5 \%$. + It differs at the $5 \%$ level of significance by the Dunnett test for pure nanoparticles. ${ }^{*}$ Differs at the $5 \%$ level of significance by the Dunnett test for $\mathrm{ZnO}$.

Despite of pure $\mathrm{ZnO}$ NPs (100 and 10 $\left.\mathrm{mg} \mathrm{mL} \mathrm{m}^{-1}\right)$, and $\mathrm{FeO}, \mathrm{MnO}\left(100 \mathrm{mg} \mathrm{mL}^{-1}\right)$ did not inhibit bacterial growth, $\mathrm{ZnO}$ NPs doped with Fe and Mn have shown antibacterial activity. This can be explained due to the increase of interaction between oxygen and dehydrogenase enzyme when $\mathrm{ZnO}$ NPs was doped with Fe and Mn, which improved the antibacterial activity by the generation of ROS (SHARMA et al. 2016).

The area under the disease progress curve (AUDPC), for MWS, in the curative or preventive application of NPs reduced disease severity compared with the control (Table 3), in both assays. In the first assay (5 and $10 \mathrm{mg} \mathrm{mL}^{-1}$ ), a similar AUDPC was observed between the NPs and the control (Table 3).
In the second assay, the NPs of $\mathrm{ZnO}: 0.1 \mathrm{Cu}$ at 2.5 and $5 \mathrm{mg} \mathrm{mL}^{-1}$ (3.1 and 2.3), and $\mathrm{ZnO}: 0.2 \mathrm{Mn}$ at 2.5 and 5 $\mathrm{mg} \mathrm{mL}^{-1}$ (4.1 and 4.9) reduced the severity of MWS, in both applications. Otherwise the $\mathrm{ZnO}: 0.05 \mathrm{Fe}$ and $\mathrm{ZnO}$;07Ni did not reduce the disease severity, in the second assay; also they did not control the MWS.

The $\mathrm{ZnO}: 0.1 \mathrm{Cu}$ and $\mathrm{ZnO}: 0.2 \mathrm{Mn}$ NPs significantly reduced MWS, in preventive and curative applications, showing a similar result with the in vitro experiment. The concentrations of the NPs -2.5 or $5 \mathrm{mg} \mathrm{mL}^{-1}$ - did not show signs of phytotoxicity to maize plants.

The concentration and particle size used must be considered when spraying NPs. In a previous test in a greenhouse, high concentrations of NPs (20 
Table 3 - Area under the disease-progress curve (AUDPC) of the maize white spot, in preventive and curative application of different nanoparticles at different concentrations, in different assays.

\begin{tabular}{|c|c|c|c|c|c|c|c|c|}
\hline \multirow{3}{*}{ NPs } & \multicolumn{4}{|c|}{ 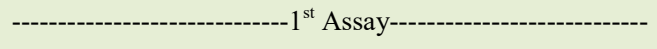 } & \multicolumn{4}{|c|}{ - } \\
\hline & \multirow[t]{2}{*}{ Concentration $\left[\mathrm{mg} \mathrm{mL}^{-1}\right]$} & \multicolumn{3}{|c|}{-----------AUDPC------------ } & \multirow[t]{2}{*}{ Concentration $\left[\mathrm{mgmL}^{-1}\right]$} & \multicolumn{3}{|c|}{-----------AUDPC----------. } \\
\hline & & $\mathrm{C}$ & $\mathrm{P}$ & Mean & & $\mathrm{C}$ & $\mathrm{P}$ & Mean \\
\hline $\mathrm{ZnO}: 0.1 \mathrm{Cu}$ & 5 & 3.8 & 3.0 & $3.4 \mathrm{~A}$ & 2.5 & $3.3^{*}$ & $2.9^{*}$ & $3.1 \mathrm{~A}$ \\
\hline $\mathrm{ZnO}: 0.1 \mathrm{Cu}$ & 10 & 6,9 & 5,0 & $5,9 \mathrm{~A}$ & 5 & $3.0^{*}$ & $1.5^{*}$ & $2.3 \mathrm{~A}$ \\
\hline $\mathrm{ZnO}: 0.05 \mathrm{Fe}$ & 5 & 5.9 & 4.6 & $5.3 \mathrm{~A}$ & 2.5 & 7.8 & 8.8 & $8.3 \mathrm{~B}$ \\
\hline $\mathrm{ZnO}: 0.05 \mathrm{Fe}$ & 10 & 6.5 & 4,4 & $5.4 \mathrm{~A}$ & 5 & 7.9 & 8.5 & $8.2 \mathrm{~B}$ \\
\hline $\mathrm{ZnO}: 0.2 \mathrm{Mn}$ & 5 & 4.0 & 2.3 & $3.1 \mathrm{~A}$ & 2.5 & $3.0^{*}$ & 5.3 & $4.1 \mathrm{~A}$ \\
\hline $\mathrm{ZnO}: 0.2 \mathrm{Mn}$ & 10 & 4.3 & 5.9 & $5.3 \mathrm{~A}$ & 5 & 3.8 & 6.0 & $4.9 \mathrm{~A}$ \\
\hline $\mathrm{ZnO}: 0.7 \mathrm{Ni}$ & 5 & 4.4 & 6.4 & $5.4 \mathrm{~A}$ & 2.5 & 6.5 & 7.9 & $7.2 \mathrm{~B}$ \\
\hline $\mathrm{ZnO}: 0.7 \mathrm{Ni}$ & 10 & 4.6 & 5.8 & $5.1 \mathrm{~A}$ & 5 & 7.3 & 5.8 & $6.5 \mathrm{~B}$ \\
\hline Control $^{*}$ & \multicolumn{4}{|c|}{--------10.50------ } & & \multicolumn{3}{|c|}{-------10.00----- } \\
\hline Means & & $5.0 \mathrm{a}$ & $4.7 \mathrm{a}$ & & & $5.3 \mathrm{a}$ & $5.8 \mathrm{a}$ & \\
\hline
\end{tabular}

NPs: nanoparticles; C: Curative application; P: Preventive application; Control: with water application.

Means followed by uppercase letters in the column and lowercase letters in the row differ by the Scott-Knott test at $5 \%$. ${ }^{*}$ Differs at the $5 \%$ level of significance by Dunnett's test.

$\mathrm{mg} \mathrm{mL} \mathrm{m}^{-1}$ ) caused phytotoxicity to maize plants. The size of the NPs, around $20 \mathrm{~nm}$, its rod shape, and the lower concentrations of the doping element leads to an increase in the contact surface (SANTANA et al., 2015), facilitating its penetration (ELMER \& WHITE, 2016) and; consequently, favoring bacterial death.

Copper hydroxide and copper oxychloride used for the control of Pantoea ananatis had a phytotoxic effect on maize plants (BOMFETI et al., 2007). Thus, in the management of MWS, ZnO:0.1Cu NPs can be a good alternative to copper-based bactericides, also $\mathrm{ZnO}: 0.2 \mathrm{Mn}$ NPs, since they reduced the severity of the disease without causing phytotoxicity.

This is the first report of the use of $\mathrm{ZnO}$ NPs doped with $\mathrm{Cu}, \mathrm{Fe}, \mathrm{Mn}$ and $\mathrm{Ni}$ for the control of MWS. Other essays should be carried out using another concentrations to assess their efficacy in controlling the disease.

The study reported out that $\mathrm{ZnO}$ NPs doped with $\mathrm{Ag}, \mathrm{Au}, \mathrm{Cu}, \mathrm{Fe}, \mathrm{Mn}, \mathrm{Ni}$ in different concentrations, and pure $\mathrm{NPs} \mathrm{Ag}_{2} \mathrm{O}, \mathrm{CuO}$ and $\mathrm{NiO}$ inhibited growth of $P$. ananatis in vitro. $\mathrm{ZnO}: 0.1 \mathrm{Cu}$ and $\mathrm{ZnO}: 0.2 \mathrm{Mn}$ reduced the severity of MWS in preventive and curative applications, being a promising technology for the management of MWS.

\section{ACKNOWLEDGEMENTS}

The authors are grateful to the Coordenação de Aperfeiçoamento de Pessoal de Nível Superior - Brazil (CAPES) Financing Code 001, for the support extended until the completion of this study.

\section{DECLARATION OF CONFLICT OF INTEREST}

We have no conflict of interest to declare.

\section{AUTHORS' CONTRIBUTIONS}

The authors contributed equally to the manuscript.

\section{REFERENCES}

AHAMED, M. et al. Synthesis, characterization and antimicrobial activity of copperoxide nanoparticles. Journal Nanomaterials, v.2014, p.1-4, 2014. Available from: <https://doi.org/10.1155/2014/637858>. Accessed: Sept. 15, 2020. doi: 10.1155/2014/637858.

ALLAKER, R. P. The use of nanoparticles to control orel biofilm formation. Jornal of Dental Research, v.89, p.1175-1186, 2010. Available from: $<$ https://doi.org/10.1177\%2F0022034510377794>. Accessed: Sept. 15, 2020. doi: 10.1177\%2F0022034510377794.

ARAÚJO, E. A. et al. Sanitization of minimally processed carrot with silver nanoparticles. Ciência Rural, v.45, n.9, p.1681- 
1687, 2015. Available from: <https://doi.org/10.1590/01038478cr20130820>. Accessed: Jul. 30, 2020. doi: 10.1590/0103$8478 \mathrm{cr} 20130820$.

BALLOTTIN, D. et al. Antimcrobial textiles: Biogenic silver janrticles against Candida and Xanthomonas. Materials Science and Engineering C, v.75, n.1, p.582-589, 2017. Available from: $<$ https://doi.org/10.1016/j.msec.2017.02.110>. Accessed: Sept. 15, 2020. doi: 10.1016/j.msec.2017.02.110.

BOMFETI, C. A et al. Evaluation of commercial chemical products, in vitro and in vivo in the control of foliar disease, maize white spot, caused by Pantoea ananatis. Summa Phytopathologica, v.33, n.1, p.63-67, 2007. Available from: <https://doi.org/10.1590/ S0100-54052007000100009>. Accessed: Sept. 15, 2020. doi: 10.1590/S0100-54052007000100009.

CAMPBELL, C. L.; MADDEN, L. V. Introduction to plant disease epidemiology. Wiley, 1990.

CASELA, C. R.; et al. Doenças na cultura do milho. Sete Lagoras, Dez. 2006. Circular Técnica 83. Online. Available from: $<$ https://www.infoteca.cnptia.embrapa.br/bitstream/doc/490415/1/ Circ83.pdf $>$. Accessed: Jun. 21, 2021.

COSTA, R.V. et al. Efficiency of fungicides to control maize white spot. Revista Brasileira de Milho e Sorgo, v.11, n.3, p.291-301, 2012. Available from: <https://www.alice.cnptia.embrapa.br/ bitstream/doc/960461/1/Eficienciafungicidas2.pdf $>$. Accessed: Dec. 17, 2020. doi: 10.18512/1980-6477/rbms.v11n3p291-301.

CUI, Y. et al. The molecular mechanism of action of bactericidal gold nanoparticles on Escherichia coli. Biomaterials, v.33, p.2327-2333, 2012. Available from: <https://doi.org/10.1016/j. biomaterials.2011.11.057>. Accessed: Sept. 15, 2020. doi: 10.1016/j.biomaterials.2011.11.057. '

DURÁN, N. et al. Silver nanoparticles: A new view on mechanistic aspects on antimicrobial activity. Nanomedicine: Nanotechnology, Biology and Medicine, v.12, n.3, p.789-799, 2016. Available from: $<$ https://doi.org/10.1016/j.nano.2015.11.016>. Accessed: Jun. 11, 2021. doi: 10.1016/j.nano.2015.11.016.

ELMER, W. H.; WHITE, J. C. The use of metallic oxide nanoparticles to enhance growth of tomatoes and eggplants in disease infested soil or soilless medium. Environmental Science: Nano, v.3, n.5, p.1072-1079, 2016. Available from: <http:// dx.doi.org/10.1039/c6en00146g >. Accessed: Sept. 15, 2020. doi: $10.1039 / \mathrm{c} 6 \mathrm{en} 00146 \mathrm{~g}$.

ELSHARKAWY, M. et al. Zinc oxide nanostructures as a control strategy of bacterial speck of tomato caused by Pseudomonas syringae in Egypt. Environmental Science and Pollution Research, v. 27, p. 19049-19057, 2020. Available from: https:// link.springer.com/article/10.1007/s11356-018-3806-0. Accessed: Jun. 17, 2021. doi: 10.1007/s11356-018-3806-0.

FIGUEIREDO, J. E. F.; PACCOLA-MEIRELLES, L. D. Simple, rapid and accurate PCR-based detection of Pantoea ananatis in maize, sorghum and Digitaria sp. Journal Plant Pathology, [S.1.], v.94, p.663-667, 2012. Available from: <http://www.sipav.org/ main/jpp/index.php/jpp/article/viewFile/2649/1325>. Accessed: Jun. 17, 2021.

FRAGA, F. S. et al. Doped zinc-oxide nanocrystals for the control of tomato bacterial spot and Xanthomonas gardneri in seeds.
Tropical Plant Pathology, p.1-8, 2021. Available from: $<$ https:// link.springer.com/content/pdf/10.1007/s40858-021-00436-2.pdf $>$. Accessed: Jun. 11, 2021. doi: 10.1007/s40858-021-00436-2.

HE, X. et al. The current application of nanotechnology in food and agriculture. Science Direct, v.27, p.1-21, 2019. Available from: <https://www.sciencedirect.com/science/ article/pii/S102194981830173X>. Accessed: Dec. 17, 2020. doi: $10.1016 /$ j.jfda.2018.12.002.

KADO, C. I.; HESKETT, M. G; Selective media for isolation of Agrobacterium, Corynebacterium, Erwinia, Pseudomonas, and Xanthomonas. Phytopathology. v.60, n.6, p.969-76, 1970. Available from: $<$ https://doi.org/10.1094/Phyto-60-969>. Acessed: Aug. 10, 2020. doi: 10.1094/Phyto-60-969.

KAH, M.; HOFMANN, T. Nanopesticide research: Current trends and future priorities, Environment International, v63, p.224-235, 2014. Available from: <https://doi.org/10.1016/j. envint.2013.11.015>. Accessed: Aug. 10, 2020. doi: 10.1016/j. envint.2013.11.015.

KEZHEN, Q. et al. Transition metal doped ZnO nanoparticles with enhanced photocatalytic and antibacterial performances: experimental and DFT studies. Ceramics International, v.46, n.2, p.1494-1502, 2020. Available from: < https://www.sciencedirect. com/science/article/pii/S0272884219326471>. Accessed: Dec. 08, 2020. doi: 10.1016/j.ceramint.2019.09.116.

LIAO, Y.-Y. et al. Nano-Magnesium Oxide: A novel bactericide against copper-tolerant Xanthomonas perforans causing tomato bacterial spot. Phytopathology ${ }^{\circledR}$, v.109, n.1, p.52-62, 2019. Available from: <https://apsjournals.apsnet.org/doi/full/10.1094/ PHYTO-05-18-0152-R>. Accessed: Jun. 15, 2021. doi: 10.1094/ PHYTO-05-18-0152-R.

OCSOY, I. et al. Nanotechnology in plant disease management: DNAdirected silver nanoparticles on graphene oxide as an antibacterial against Xanthomonas perforans. ACS Nano, v.7, n.10, p.8972-8980, 2013. Available from: $<$ https://pubs.acs.org/doi/10.1021/nn4034794>. Accessed: Jun. 15, 2021. doi: 10.1021/nn4034794.

PACCOLA-MEIRELLES, L.D. et al. Detection of a bacterium associated with a leaf spot disease of maize in Brazil. Journal of Phytopathology, v.14, n.5, p.275-279, 2001. Available from: $<$ https://doi.org/10.1046/j.1439-0434.2001.00614.x>. Accessed: Oct. 15, 2020. doi: 10.1046/j.1439-0434.2001.00614.x.

PEDRO, E.S. et al. Products of different chemical groups to control maize white spot. Semina: Ciências Agrárias, v.33, n.0, p.2981-2984, 2012. Available from: <https:// ainfo.cnptia.embrapa.br/digital/bitstream/item/88956/1/ Produtos-diferentes.pdf $>$. Accessed: Oct. 15, 2020. doi: 10.5433/1679-0359.2012v33Sup11p2981.

R CORE TEAM, R. A. Language and environment for statistical computing. R Foundation for Statistical Computing, Vienna, Austria. 2020. Available from: <https://www.R-project.org/>. Accessed: Oct. 15, 2020.

RIVAS-CÁCERES, R. R. et al. Bactericidal effect of silver nanoparticles against propagation of Clavibacter michiganensis infection in Lycopersicon esculentum Mill. Microbial Pathogenesis, v.115, n.1, p.358-362, 2018. Available from: $<$ https://doi.org/10.1016/j.micpath.2017.12.075>. Accessed: Oct. 16, 2020. doi: 10.1016/j.micpath.2017.12.075. 
SABIR, S. et al. Zinc Oxide nanoparticles for revolutionizing agriculture: synthesis and applications. The Scientific World Journal, v.2014, p.1-8, 2014. Available from: <https://www. hindawi.com/journals/tswj/2014/925494/>. Accessed: Dec. 05, 2020. doi: $10.1155 / 2014 / 925494$

SANTANA, M. C. et al. Evaluation of antimicrobial activity of silver nanoparticles. Perspectivas da Ciência e Tecnologia, v.7, n.1, p.36-45, 2015. Available from: $<$ https://revistascientificas.ifrj. edu.br/revista/index.php/revistapct/article/view/519>. Accessed: Oct. 19, 2020.

SAUER, A. V. et al. Survival of Pantoea ananatis, causal agent of maize white spot disease in crop debris. Agronomy Science and Biotechnology, v.1, n.1, p.21-24, 2015. Available from: <https:// www.embrapa.br/documents/1355291/19411098/Survival + of $+\mathrm{Pa}$ ntoea + ananatis $\% 2 \mathrm{C}+$ causal + agent + of + maize.pdf $/ 75 \mathrm{fb} 7 \mathrm{e} 94-\mathrm{a} 100$ 4c8c-9712-31469135cb2d?version=1.0>. Accessed: Jun. 15, 2021. doi: $10.33158 /$ ASB.2015v1i1p21.

SHARMA, N. et al. Synthesis, characterisation and antimicrobial activity of manganese- and iron-doped zinc oxide nanoparticles. Journal of Experimental Nanoscience, v.11, n.1, p.54-71, 2016. Available from: $<$ https://www.tandfonline.com/doi/full/10 $.1080 / 17458080.2015 .1025302>$. Accessed: Oct. 19, 2020. doi: $10.1080 / 17458080.2015 .1025302$.
SILVA, A. C. A. et al. Biocompatibility of doped semiconductors nanocrystals and nanocomposites. Cytotoxicity, InTech, p.149161, 2018. Available from: <https://www.intechopen.com/ books/cytotoxicity/biocompatibility-of-doped-semiconductorsnanocrystals-and-nanocomposites $>$. Acessed: Oct. 16, 2020. doi: 10.5772/intechopen.77197.

SILVA, T.B.; TEBALDI, N.D. Characterization of Pantoea ananatis isolates and reaction of maize genotypes to the bacterium. Summa Phytopathologica, v.44, n.3, p.283-285, 2018. Available from: $\quad<$ https://www.scielo.br/j/sp/a/xxmmNd5v8YfX5N3TyD bSfxj/?lang=pt $>$. Accessed: Jun. 17, 2021. doi: 10.1590/0100$5405 / 170862$.

VIJAYAPRASATH, G., et al. Role of nickel doping on structural, optical, magnetic properties and antibacterial activity of $\mathrm{ZnO}$ nanoparticles. Materials Research Bulletin, v.76, p.48-61, 2016. Available from: <https://www.sciencedirect.com/science/article/ pii/S0025540815302488\#bib0370>. Accessed: Dec. 10, 2020. doi: 10.1016/j.materresbull.2015.11.053.

WANG, L.; et al. The antimicrobial activity of nanoparticles: present situation and prospects for the future. International Journal of Nanomedicine, v.12, p.1227-1249, 2017. Available from: <https:// www.ncbi.nlm.nih.gov/pmc/articles/PMC5317269/>. Accessed: Jun. 15, 2021. doi: 10.2147/IJN.S121956. 